\title{
Electricity Generation in Nigeria from Municipal Solid Waste using the Swedish Waste- to-Energy Model
}

\author{
${ }^{* 1}$ AKHATOR, EP; ${ }^{2}$ OBANOR, AI; ${ }^{3}$ EZEMONYE, LI \\ ${ }^{a, b}$ Department of Mechanical Engineering, University of Benin \\ ${ }^{c}$ Department of Animal and Environmental Biology, University of Benin. \\ apeter.akhator@uniben.edu, ${ }^{b}$ aiobanor@yahoo.com, ${ }^{c}$ ezenmslaw@uniben.edu \\ "Corresponding Author: peter.akhator@uniben.edu
}

\begin{abstract}
Waste-to-energy (WTE) technology in Nigeria is still at the infancy stage whereas in Sweden the technology is now so advanced that energy in the form of heat and electricity has commercially been recovered from waste. This study examines waste-toenergy development and its success factors in Sweden with a view to instigating the deployment of a modified Sweden's waste-to-energy model in Nigeria to enhance her WTE capacity. The study was carried out in two phases. The first phase involved field visits to some waste-to-energy plants in Sweden and the second phase was a desk research of available data on current WTE development in Nigeria, Sweden's energy sector as well as factors responsible for its successful WTE development. The result from the study showed that Sweden generated about 2.0TWh of electricity from about 5.7 million tonnes of waste in its WTE plants in 2014. The success of WTE development and growth in Sweden is hugely as a result of the support from the Swedish government via enacting enabling policies and adequate funding. With about 14 million tonnes of combustible waste available in Nigeria, about 4.4TWh of electricity could be generated annually if WTE development in the country receives similar support from the Nigerian government. @ JASEM

http://dx.doi.org/10.4314/jasem.v20i3.18
\end{abstract}

Keywords: Electricity generation, Municipal solid waste, Renewable energy, Solid waste combustion, Swedish waste-to-energy model, Waste-to-energy development.

The importance of energy services to the socioeconomic development of a country has been extensively documented in literature. Access to modern energy services is closely related to improvements in other facets of human development such as healthcare, water supply, education, environmental cleanliness, job creation, food security etc. (Kanagawa et al., 2007; Sokona et al., 2012). On the contrary, poor supply of energy hinders economic growth and negatively affects the standard of life of the people. The electricity sector is of particular importance in the energy sector due to the variety of its end-use in comparison with other forms of energy. Despite having an abundance of both renewable and non-renewable energy resources notably hydro, biomass, fossil fuels, coal, and natural gas, Nigeria is still being plagued with electricity crisis, a crisis that seems without end. The electricity crisis has hampered the socio-economic and technological development of the nation and had compelled many industries to either shut down or relocate to neighbouring countries thereby reducing job availability and Gross National Product (GNP). The national peak electricity demand forecast for 2016 was put at $17,520 \mathrm{MW}$, but Nigeria has a deteriorating installed capacity of about 11,165.4MW (Nnodim, 2016). According to Transmission Company of Nigeria (TCN), the maximum electrical power generation ever recorded in the history of Nigeria is $5074.70 \mathrm{MW}$ and the highest daily energy wheeled nationwide is $109,372 \mathrm{MWh}$. This quantity falls short of the national requirement hence it is insufficient to light up every house and street in the country as it's evident from the incessant blackouts and brownouts witnessed by her residents. A direct effect of this poor electricity supply can be seen in the huge number of Nigerians who have resorted to purchasing and using alternative sources of electricity, such as generators, inverters and solar panels, for residential and commercial purposes. The average daily cumulative power supply to Nigerian households in hours per day from April 2013 to September 2015 is shown in Figure 1. 


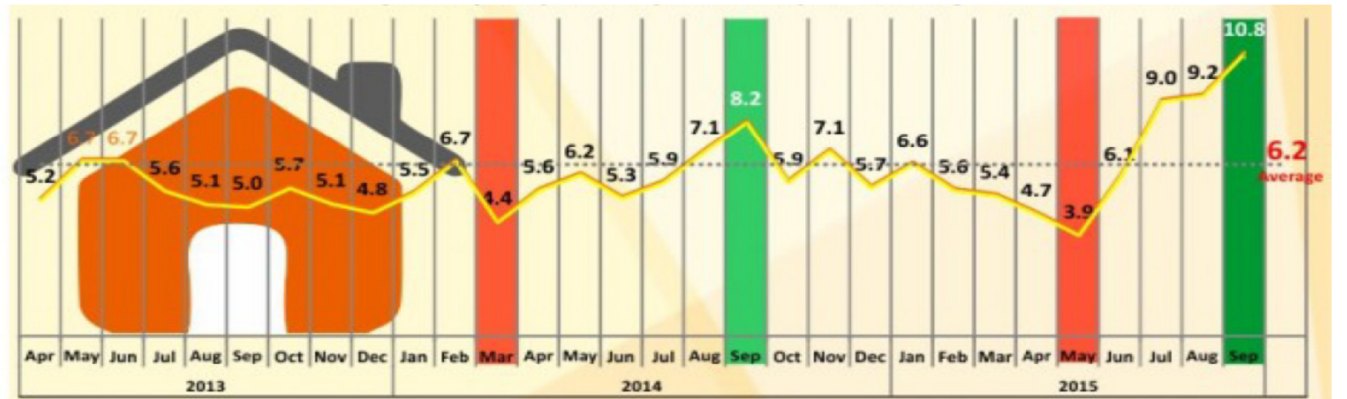

Fig 1: Average daily cumulative power supply to Nigerian households in hours/day (Ochelle, 2015).

The low electrical power generation in Nigeria can be adduced to several problems such as inadequate, inefficient and obsolete power generation plants, high incidence of equipment breakdowns and notable lack of sustainable fuel (natural gas) supply to the generation stations. A plausible solution to the low power generation in Nigeria can be the introduction of a waste-to-energy (WTE) technology that utilizes another sustainable fuel (solid waste).

The utilization of solid waste for electricity generation has already been established, for example in Sweden in 2014, about 5.7million tonnes of sorted combustible solid waste were combusted in 33 WTE plants across the country to produce about $16.6 \mathrm{TWh}$ of energy, 2.0TWh went for electricity and the remaining 14.6TWh went for district heating purposes (SWM, 2015). The heat energy released from combusting these wastes is recovered through the production of steam in boiler super-heater tubes. The steam is then utilized to generate electricity using a steam turbine generator. The heat content of steam bled from or exiting the steam turbine is high enough to be used for district heating purposes. Utilizing its wastes in this manner also provides a clean environment for Swedes to live in. The Kingdom of Sweden is a parliamentary democracy with a constitutional monarchy. Sweden, a unitary state with twenty one administrative counties, is the fourth largest country in the European Union with a population of over nine million and an area of 450,295 square kilometers. The country has her capital city as Stockholm and shares borders with Denmark, Estonia, Finland, Germany, Latvia, Lithuania, Norway, Poland and Russia (IEA, 2013).

In Nigeria, about 14 million tonnes of combustible solid waste are generated annually (Uchendu, 2008). Due to limited knowledge on modern WTE technology, these wastes are largely disposed off in dumpsites. With modern WTE technology these solid wastes could generate about $4.4 \mathrm{TWh}$ of electricity per year and their combustion in WTE plants would assist in the effort to provide a cleaner environment in the country. The electricity generated would greatly complement the current grid electricity, increase the number of hours that electricity is available and boost economic activities in Nigeria. Adopting WTE technology in Nigeria would contribute to achieving the goals of Nigeria's Renewable Energy Master Plan (REMP), which is to have biomass-based power plants with installed capacity of 50MW in 2015 and 400MW in 2025 (IEA, 2011). With the generation and distribution arms of power sector now privatized, WTE technology could present the generation companies a cheap alternative source for generating electrical energy. Additionally, the streets of Nigeria will be cleaner and healthier by combusting her solid waste in WTE plants. This paper looks at the success of waste-to-energy development in Sweden and advocates the utilization of a modified Swedish model in Nigeria to enhance electricity generation. There are several ways to generate energy from solid waste (gasification, co-digestion etc.), however, this paper concentrates only on energy recovery from solid waste through incineration.

\section{MATERIALS AND METHODS}

The study originated from the need to present solid waste as a sustainable alternative fuel for electricity generation in Nigeria using the success of the Swedish waste-to-energy model. The study involved field visits to some waste-to-energy power plants in Sweden where wastes in different forms are converted to heat and electricity. A tour of these plants was done and interviews were conducted about the development and operations of these plants. A desk research was also carried out to assess existing data on current WTE development in Nigeria, Sweden's energy sector as well as its waste-to-energy development. Several key factors attributable to successful deployment of waste-to-energy capacities and the degree to which these factors have contributed to Sweden's significant achievement on waste-to-energy front were examined. 


\section{RESULTS AND DISCUSSION}

History of Energy and Waste-to-Energy in Sweden: Sweden is hugely regarded as a waste-to-energy success story. In 2014, Sweden was adjudged to recover more energy from waste than any other European country, harnessing approximately $3 \mathrm{MWh}$ per tonne of solid waste (SWM, 2015). However, this success was not achieved in a day; Sweden has come a long way of harnessing energy from waste. The first waste incineration plant with energy recovery was commissioned in 1904. Sweden began to significantly expand its district heating network in the late 1940s, paving way for waste-to-energy development in later decades. The oil shocks of the 1970s left Sweden extremely vulnerable; hence she introduced nuclear and re-introduced coal to her energy mix and started a major expansion of wasteto-energy plants. Despite the re-emergence of coal as a major source of energy in the 1980s, Sweden has turned to renewable energy resources such as wind, bio-fuels, and waste due to her decision to be more eco-friendly and less reliant on foreign energy sources.

Renewable energy has been pivotal in Sweden's quest to become independent of fossil fuels. In 2013, Sweden achieved her goal of producing half of her total energy from renewable energy sources several years ahead of the Swedish government's 2020 schedule. The 2013 figure of 52\% for renewable energy contribution, including electricity, district heating and transportation fuels, was the highest in the European Union (The Swedish Institute, 2016). Figure 2 shows the renewable energy contribution to Sweden's energy sector in 2013.

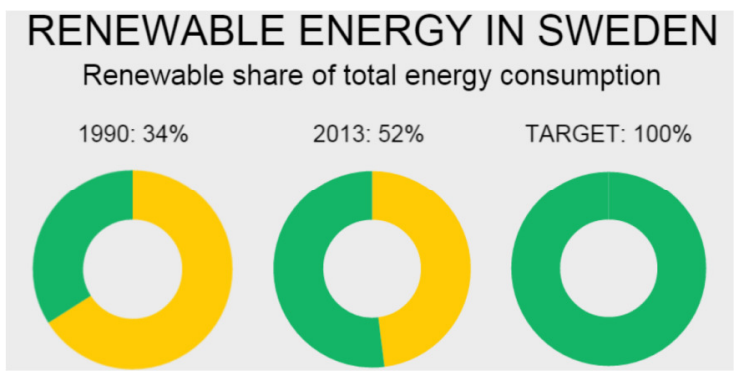

Fig 2: Renewable energy contribution to Sweden's energy mix (The Swedish Institute, 2015a).

Sweden generates almost all of her electricity from nuclear and hydro, but is increasingly moving towards biomass and waste-to-energy (Florea, 2011). Thus far, Sweden has substantially reduced her consumption of fossil fuels since the early 1980s. In 2013, fossil fuels accounted for less than $30 \%$ of the total energy supply in the country (Swedish Energy Agency, 2015). In 2016, oil accounted for about $20 \%$ of Swedish energy supply, mainly due to the decline in the usage of oil for residential heating (The Swedish Institute, 2016).

One of the main contributors to increase in renewable energy has been bio-fuels and biomass. The total energy generated from biomass in Sweden grew from 88TWh in 2010 to 129TWh in 2013 (Swedish Energy Agency, 2015).

Expansion of Waste-to-Energy in Sweden: Waste-toenergy has expanded rapidly since late 1990s. From 1994 to 2014, waste incineration with energy recovery has contributed immensely to waste treatment in the country, increasing from $39 \%$ to $47.3 \%$ over the period. According to SWM (2015), Sweden's energy recovery capacity from waste is more than the domestic available combustible waste, hence in 2104 alone, over one million tonnes of waste was imported for energy recovery. Energy recovery has contributed more to increased waste diversion from landfills in Sweden than in other European countries (SWM, 2015). In 2014, about 2.15 million tonnes of sorted combustible household wastes and over 3.55 million tonnes of other sorted combustible wastes, mainly industrial wastes, were treated in 33 Swedish waste-to-energy facilities to generate a total of $16.6 \mathrm{TWh}$ of energy comprising 14.6TWh th and 2.0TWh $\mathrm{TW}_{\mathrm{el}}$ (SWM, 2015). Table 1 shows the amount of energy harnessed from waste in Sweden's WTE facilities from 2010 to 2014. Figure 3 shows the amount of energy recovered from waste and the quantity of waste treated in Sweden from 1985 to 2014. 
Table 1: Energy recovery from waste in Sweden (SWM, 2015)

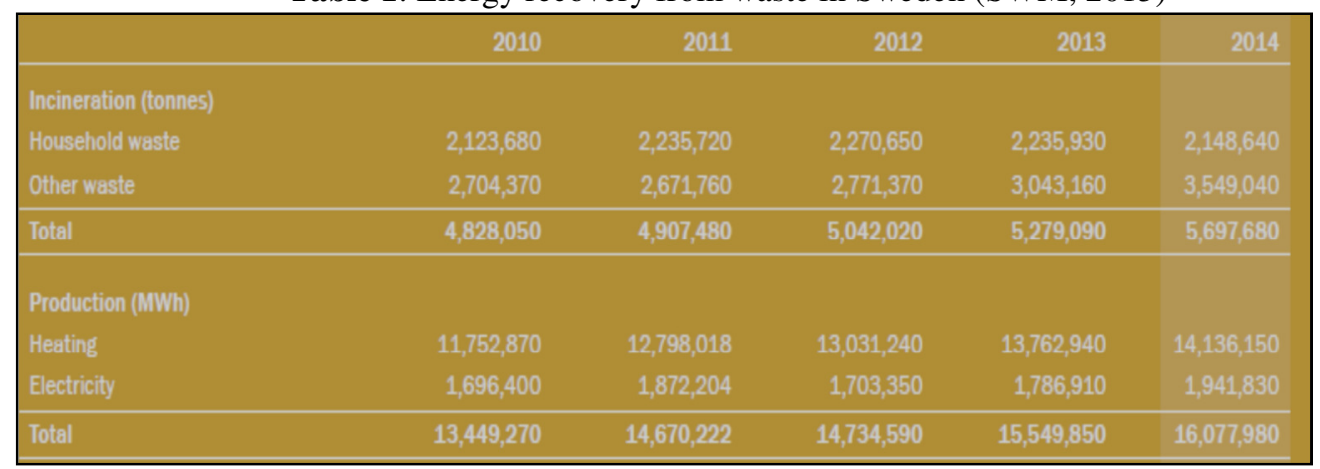

Table 2: Amount of energy recovered from waste and the quantity of waste treated in Sweden (SWM, 2015).

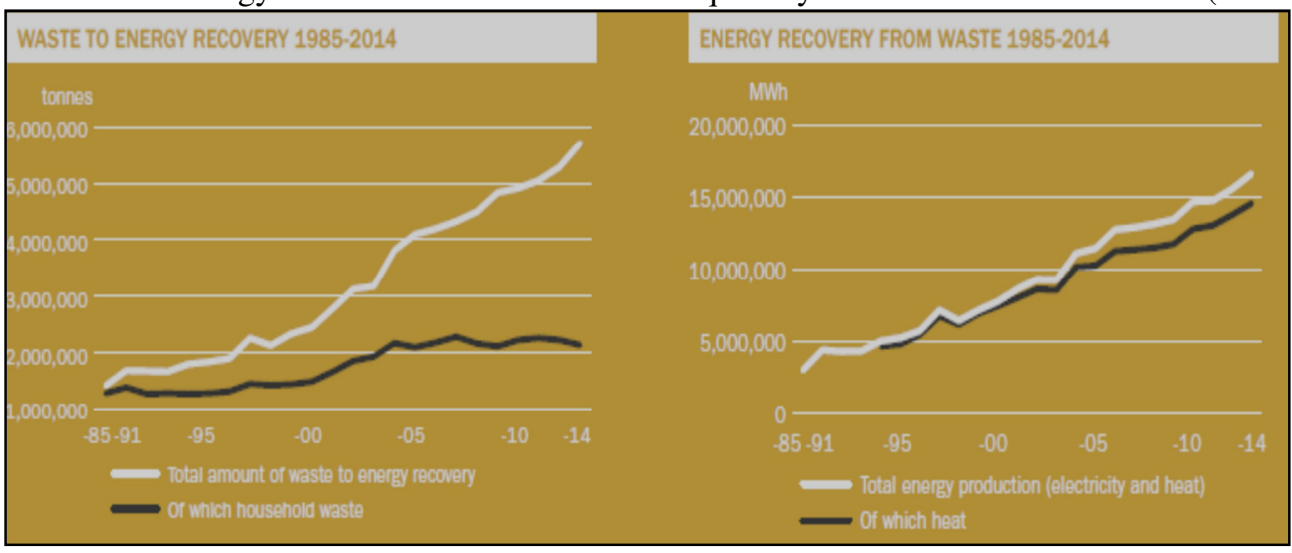

Waste-to-Energy Success Factors: This section presents analysis of some success factors that could aid in successful deployment of waste-to-energy capacities and the degree to which these factors have contributed to Sweden's significant achievement on waste-to-energy front.

A. High landfill fees: This is probably the major driver of waste-to-energy. High tipping fees can prohibit dumping of waste in landfills and make energy recovery a more economical alternative method of disposing waste. Despite the vast available land in Sweden, her landfills are expensive. In 2011, Sweden's average tipping fees was equivalent to about $\$ 193$ per tonne of waste (Gersham, 2013).

B. National policies supporting waste-to-energy: Government policies can be crucial to WTE being an economical option for electricity production. In Sweden, there have been several government and EU policies geared towards encouraging the development of waste-to-energy capacities. Some of the policies that can be instrumental in promoting WTE development are delineated as follows:

Recognizing waste-to-energy as renewable source of energy: Recognizing waste-to-energy as a renewable source of energy by governments can create incentives and programmes that could encourage waste-to-energy development. In Sweden and in other EU countries waste is recognized as renewable source of energy (Bjork, 2012).

Renewable portfolio standards (RPS): Renewable portfolio standards are regulatory mandates to increase energy production from renewable sources of energy. It obligates electricity retailers to provide a certain percentage of electricity from renewable sources of energy. As stated earlier, Sweden has a target to generate half of its total energy from renewable energy resources by 2020 .

Direct subsidies: Subsidies can be in various forms such as tax credits, production grants, import duties, feed-in-tariffs, low interest loans to producers or 
depreciation allowances. Sweden currently offers depreciation allowances for wind energy facilities and operating subsidies for each MWh produced from renewable sources (KPMG, 2014). These subsidies can be extremely effective for growing renewable industries due to the high capital cost.

Carbon tax: Placing a high enough price on greenhouse gas emissions creates incentives for emitters to reduce emissions. A price on greenhouse gas comes in the form of carbon tax. According to the Swedish Bioenergy Association, Sweden introduced carbon tax in 1990 and has witnessed fast economic growth and reduced emissions since then. Sweden's carbon tax made it much more expensive to produce energy from coal and fossil fuels leading many power plants to resort to biomass as feedstock (Fouche, 2008). It was reported by the Swedish Bioenergy Association that greenhouse gas emissions decreased by $25 \%$ from 1990 to 2014 and the use of bio-energy doubled. In 2014, biomass accounted for over $22 \%$ of total energy consumption in Sweden, (Swedish Energy Agency, 2015) and as of 2010 wood-fired district heating systems satisfied more than $50 \%$ of her residential heat demand (Gibson, 2010). The carbon tax also proved to be an important source of income for the Swedish government, raking in about 28million Swedish Krona.

Preference for waste-to-energy in the solid waste management hierarchy: In the 2008 EU Waste Framework Directive, the five stages of the waste management hierarchy are introduced as waste reduction, reuse, material recycling, energy recovery and waste disposal as shown in Figure 4. The Integrated Solid Waste Management (ISWM) hierarchy stipulates that source reduction and reuse are the most desirable solid waste management practices since they are the most effective way to reduce the quantity of waste and resource consumption, followed by recycling/composting. However, after waste is reduced, reused and recycled, waste is still leftover and must be managed further. Here combustion with energy recovery becomes necessary. Sweden prefers waste reduction, reuse and recycling to energy recovery, and prefers energy recovery to landfilling.

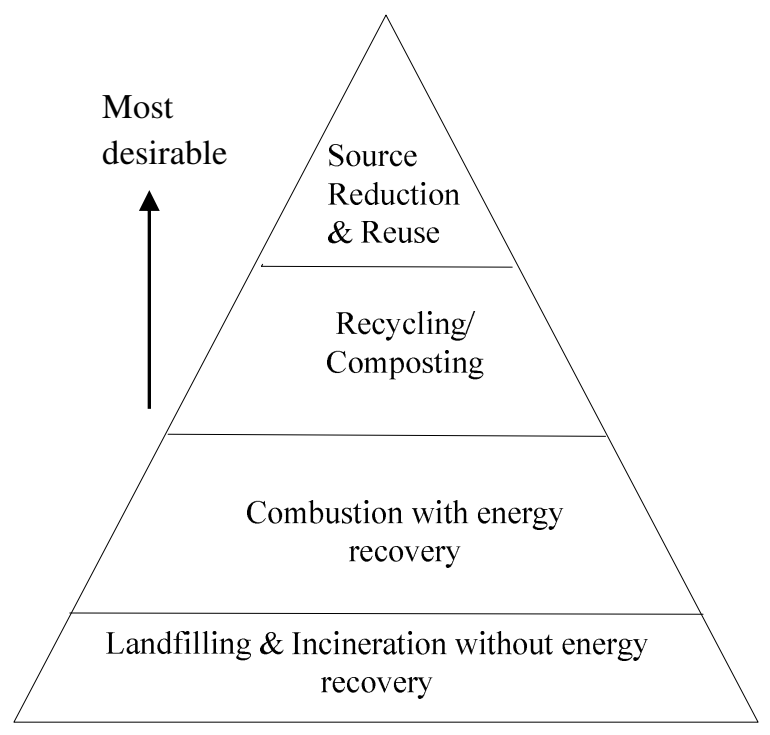

Fig 4: Integrated SWM hierarchy.

High landfill charges: High landfill charges help to encourage material and energy recovery from waste. In Europe, these charges have proven to be hugely effective in diverting wastes from landfills and encouraging growth in waste-to-energy industries (EEA, 2009). In Sweden, since 2006 the landfill tax alone on wastes sent to landfills has been about 435 Swedish Krona per tonne. This has made it more expensive to dispose wastes in landfills and is one of the main reasons Sweden has such a high recycling rate (SWM, 2010). Other policies that have helped divert wastes away from Sweden's landfills include EU landfill directive of 1999, Swedish ban on landfilling of combustible wastes in 2002, Swedish ban on landfilling of organic waste in 2005 and EU waste framework directive of 2008.

C. High Electricity tariffs: With high electricity tariffs energy producers from wastes can get a higher price for the energy they produce. The price of electricity has been considerably higher in Sweden than it is for example in US. Currently electricity price in Sweden stands at $\$ 0.21$ per $\mathrm{kWh}$ (Eurostat, 2016).

D. Ample supply of waste: For waste-to-energy to be a viable energy source waste must be available in adequate supply to use as feedstock. The average Swede produced about $220 \mathrm{~kg}$ and the entire country produced about 5.7 billion $\mathrm{kg}$ of waste in 2014 (SWM, 2015). Despite the growing supply of waste, Sweden now has more waste-to-energy capacity than the waste produced locally. As a result, Sweden imports waste from other countries to fuel their WTE plants. In 2009, Sweden imported 36,480 tonnes of 
waste and in 2014 she imported 1,420,900 tonnes of waste for energy production (SWM, 2015).

E. Extensive district heating network: Using MSW for combined heat and electricity purposes improves the efficiency of waste-to-energy plants considerably. Sweden has a long history of district heating especially for urban areas. Sweden's district heating network was expanded considerably in the late 1940s creating an outlet for energy from waste incineration (Walat, 2011). In 2015 19\% of the district heating in Sweden was produced from waste-to-energy plants (Braw, 2015).

F. Public support: Sweden is famous for its commitment to the environment and knowledge of environmental issues. In a 2008 poll, about $87 \%$ of Swedes proclaimed to have personally taken action to reduce their $\mathrm{CO}_{2}$ emissions and this is the highest percentage among European countries (European Parliament, 2008). Although most Swedes prefer recycling to waste-to-energy, they are generally in support of waste-to-energy as a waste disposal method as the number of plants has increased, and as control and improved technology have decreased the emissions from Swedish WTE plants by over $90 \%$ since the 1980 s.

G. High Recycling Rate: Although recycling and waste-to-energy might appear to be in direct competition with each other, there is a strong link between WTE utilization and recycling (Minnesota
Pollution Control Agency, 2010). It is preferable to recycle materials, such as metal and glass, to sending them to WTE plants as they provide no energy potential. Although, recycling may not directly lead to waste-to-energy, it is obvious that better recycling culture translates to better energy recovery from waste.

Sweden has one of the best recycling rates in the world, with over $99 \%$ recycling rate including energy recovery (The Swedish Institute, 2015b). This results in less than $2 \%$ of wastes ending up in landfill.

H. Investing in Research and Development: The public are unlikely to support renewable energy development if they know little about it. The Swedish government introduced the so called 'energy advisors', whose job is to propagate information about benefits of renewable energy and to give proper advice to the public on how to become more eco-friendly. Consequently, there is hardly a Swede today who has not heard about renewable energy while the majority of Swedes are in strong support of renewable energy development. The growing interest in sustainability also led to the creation of dozens of programmes in Universities across Sweden, which offer courses on anything from engineering to economics of clean energy, including waste-toenergy.

Table 2 shows a summary of these success factors as they relate to Sweden and Nigeria.

Table 3: Waste-to-Energy Success Factors.

\begin{tabular}{lll}
\hline Success Factors & Sweden & Nigeria \\
\hline High tipping fees & Yes & No \\
Policies favouring WTE & Yes & Partial \\
Carbon tax & Yes & No \\
High landfill charges & Yes & No \\
Recognizing WTE as renewable resource & Yes & Partial \\
Preference of WTE in waste management hierarchy & Yes & No \\
Renewable portfolio standards & Yes & No \\
Direct subsidies & Yes & Partial \\
Extensive district heating network & Yes & No \\
Ample supply of waste & Yes & Yes \\
Shortage of cheap domestic source of energy & Yes & Yes \\
Lack of cheap land for landfill & Yes & No \\
High price of electricity & Yes & Partial \\
Public support & Yes & Partial \\
High recycling rate & Yes & No \\
\hline
\end{tabular}

* Partial indicates that either the success factor may exist in certain locations within the country, or it exists to a lesser degree.

Waste-to-Energy Capacity in Nigeria: The Federiil Government of Nigeria had tried to tackle the problems of solid waste management over the years by rolling out several legislation and regulations on waste management, which includes:

The Harmful Waste Act, 1998;

Environmental Impact Assessment Act, 1992;

The National Environmental Standards and Regulations Enforcement Agency Act, 2007;

National Environmental Regulations, 2009; 
The National Environmental Protection Regulations

The formulation and implementation of such incoherent policies with respect to standard practice in the waste management sector has made solid waste management to be commonly seen in the country as simply "pick up the waste and go dump it in the dumpsite" whether it is approved dumpsite or illegal dumpsite. The waste managers collect wastes from households, markets and business premises and discharge them in dumpsites around the country thereby wasting the wastes. Open air burning without pollution control or energy recovery of the wastes is carried out at the dumpsites to reduce their volume. However, some states have gone beyond just picking up these wastes and discharging them in dumpsites to embark on setting up systems to harness energy and materials from these wastes. For example, Lagos State in partnership with a private company (WestAfricaENRG) has embarked on material recovery from waste since 2014 . The company receives wastes from either waste managers or scavengers and sorts the wastes to recover valuable fractions, like paper, metals, glasses, plastics, etc., and sell them to be processed and used again. This leaves electricity generation from waste a yet to be explored waste management option in Nigeria.

The potentials of waste-to-energy technology in Nigeria have been extensively documented in several literatures (Akhator et al., 2016; Tsunato et al., 2015; Agbo et al., 2011; Amber et al., 2012; Suberu et al., 2012). However, limited knowledge on WTE development and deployment in Nigeria has hampered the translation of these findings into physical gains. The Nigerian government needs to take proactive steps to enhance WTE development in the country as there are huge energy and environmental benefits to be derived from such technology. It has been revealed that Sweden generates about 2.0TWh of electricity annually from waste-to-energy plants and creates a clean environment for her citizens to live in the process. This quantity of electricity is greater than the maximum electricity ever generated in Nigeria. Several success factors attributable to waste-toenergy growth in Sweden have been highlighted in this paper. With the exception of extensive district heating network, all other factors can be adopted in Nigeria to develop waste-to-energy capacity in the country. Development of waste-to-energy in Nigeria would add about $4.4 \mathrm{TWh}$ of electricity to the national electricity grid annually and address massively the epileptic electricity supply and poor waste management methods in the country.
Conclusion: This study revealed that solid wastes are commercially being treated in WTE plants to generate electricity. In 2014, Sweden generated about 2.0TWh of electricity from solid wastes indicating the advancement of WTE capacity in the country. Several factors attributed to the successful development of WTE capacity in Sweden were highlighted; chief of these factors is the support from the Swedish government provided through policies favourable to and adequate investment in WTE development in the country. With similar support for WTE development in Nigeria from the Nigerian government, WTE capacity could lead to the generation of about 4.4TWh of electricity annually in the country.

\section{REFERENCES}

Agbo, KE; Eze, JI (2011). Anaerobic digestion of municipal solid waste for generation of energy: prospects and challenges in Nigeria. Nigeria Journal of Solar Energy, 22: 130-137.

Akhator, EP; Obanor, AI; Igbinomwanhia. DI (2016). Thermal analysis of a small scale solid wastefired steam boiler for power generation in Benin City, Nigeria. Nigerian Journal of Technology, 35 (3): 551-561.

Amber, I; Kulla, DM; Gukop,N (2012). Generation, characteristics and energy potential of solid municipal solid waste in Nigeria. Journal of Energy in Southern Africa 23 (3): 47-51.

Bjork, H (2012). Zero Waste Society in Borås City, Sweden: Strategies to Action. Available at www.uncrd.or.jp/content/documents/Hans\%20Bj ork-Sweden.pdf. (Accessed on March/19/2016).

Braw, E 2015, 'Dirty power: Sweden wants your garbage for energy', Aljazeera America, 25 March. Available at www.america.aljazeera.com/articles/2015/3/27/s weden-wants-your-garbage-for-energy.html, (Accessed on May/10/2016).

EEA (2009). Diverting waste from landfill: Effectiveness of waste management policies in the European Union: an EEA pilot study. European Environmental Agency, Copenhagen. (Accessed on April/6/2016).

European Parliament (2008). Climate change poll reveals $61 \%$ have taken action. Available at www.europarl.europa.eu/sides/getDoc.do?type $=\mathrm{I}$ M-PRESS\&reference 
$\equiv 20080911 \mathrm{STO} 36944 \&$ language $=$ SK. . Accessed on March/30/2016).

Eurostat (2016). Electricity price statistics. Available atwww.ec.europa.eu/eurostat/statisticsexplained/index.php/Electricity_price_statistics\# Electricity_prices_for_household_consumers. (Accessed on June/2/2016).

Florea, M 2011, 'Sweden, the top most eco friendly country in the world'. Shocking News, 10 February. Available at http://www.shockingnews.org/world/sweden thetopmostecofriendlycountryintheworld/.

(Accessed on March/3/2016).

Fouche, G 2008, 'Sweden's carbon tax solution to climate change puts it top of the green list', TheGuardian, 29 April. Available at https://www.theguardian.com/environment/2008/ apr/29/climatechange.carbonemissions.

Gersham, H 2013, 'The US can learn from Sweden', Renewable Energy from Waste, 12 February. Available http://www.rewmag.com/article/rew0213sweden wasteleader/. (Accessed on January/20/2016).

Gibson, L 2010, 'Biomass sweet spot', Biomass Magazine, 23 November. Available at www.biomassmagazine.com/articles/5146/bioma ss-sweet-spot. (Accessed on June/2/ 2016).

IEA (2011). Nigeria Renewable Energy Master Plan. Available atwww.iea.org/policiesandmeasures/pams/nigeri a/name-24808-en.php? (Assessed on February/5/2015).

IEA (2013). Energy policies of IEA countries Sweden 2013 review. Available at www.iea.org/textbase/nppdf/free/2013/sweden20 13 excerpt.pdf. (Accessed on

February/15/2016)

Kanagawa, M; Nakata, T (2007). Analysis of the energy access improvement and its socioeconomic impacts in rural areas of developing countries. Ecological Economics, 62(2): $\quad 319-329$.

KPMG (2014). Taxes and incentives for renewable energy. Available at https://www.kpmg.com/Global/en/IssuesAndInsi ghts/ArticlesPublications/Documents/taxes- incentives-renewable-energy-v1.pdf. (Accessed of March/19/2016).

Minnesota Pollution Control Agency (2010). Wasteto-energy(WTE) in an integrated solid waste management system. Available at www.pca.state.mn.us/sites/default/files/w-sw802.pdf. (Accessed on March/30/2016).

Nnodim, O 2016, 'Power generation crashes to 1,400MW', Punch Newspaper, 18 May. Available at http://www.punchng.com/powergenerationcrashe s1400mwtcn/. (Accessed on June/7/2016).

Ochelle, FO (2015). 'Nigeria's power generation is now 4,600 megawatts: will this speed up the impending electricity tariff hike?', Ventures Africa, 7 June. Available at http://venturesafrica.com/powergenerationinnige rianow4600megawattswillthisspeedup the impending electricity tariff hike/. (Accessed on June/7/2016).

Sokona, Y; Mulugetta, Y; Gujba, H ( 2012). Widening energy access in Africa: Towards energy transition. Energy Policy, 47 (1): 310.

Suberu, MY; Mokhtar, AS; Bashir, N (2012). Renewable power generation opportunity from municipal solid waste: a case study of Lagos metropolis, Nigeria. Journal of Energy Technologies and Policy, 2 (2): 2224 - 2239.

Swedish Bioenergy Association. Carbon tax - key instrument for energy transition! Available at www.svebio.se/sites/default/files/Carbon\%20tax \%20Paper_COP21.pdf. (Accessed on May/10/2016).

Swedish Energy Agency (2015). Energy in Sweden. Available at www.energimyndigheten.se/globalassets/statistik lovergripande-rapporter/energy-in-sweden-tillwebben.pdf. (Accessed on February/4/2016).

SWM (2010). Swedish Waste Management. Available at www.avfallsverige.se/fileadmin/uploads/Statistik filer/SWM2010.pdf. (Accessed on June/ 2/2016)

SWM (2015). Swedish Waste Management. Available at www.avfallsverige.se/ 
fileadmin/uploads/Rapporter/SWM_2015.pdf. (Accessed on June/2/2016).

The Swedish Institute (2015a). From resource economy to bioeconomy. Available atwww.sweden.se/climate/\#from-resourceeconomy-to-bioeconomy. (Accessed on January/20/2016).

The Swedish Institute (2015b). The Swedish recycling revolution. Available at www.sweden.se/nature/the-swedish-recyclingrevolution/ (Accessed on January/20/2016).

The Swedish Institute (2016). Energy: generating power for a sustainable future. Available athttps://sweden.se/society/energy-use-insweden/ (Accessed on March/10/2016).
Transmission Company of Nigeria (2016). Power transmission attains new peaks of 5074.7MW \& 109,372MWh. Available at

http://www.tcnorg.com/index.php/component /content/ article/7news/297powertransmissionattainsnewp eaksof5074mwand109372mwh. (Accessed on June/17/2016).

Tsunatu, DY; Tickson, TS; Sam, KD; Namo, JM (2015). Municipal solid waste as alternative source of energy generation: a case study of Jalingo metropolis- Taraba State. International Journal of Engineering and Technology, 5(3): 185-193.

Uchendu, C (2008). Municipal solid waste treatment and recycling technologies for developing countries: A typical Nigeria case study. Journal of Solid Waste Treatment and Management, 34: 127-135. 